\title{
Employee Empowerment and Its Importance for Trust, Innovation and Organizational Performance
}

\author{
Sarra BERRAIES \\ Associate professor, ISIGK, University of Kairouan, Tunisia \\ E-mail: sarraberraies610@yahoo.fr \\ Mehrez CHAHER \\ Professor, University of Tunis, Tunisia \\ E-mail: chahermehrez@yahoo.fr \\ Karim BEN YAHIA \\ Associate Professor, ISBAM, University of Gabés, Tunisia \\ E-mail: karim_b_yahia@yahoo.fr
}

Received: February 17, 2014 Accepted: June 3, 2014 Published: November 5, 2014

doi:10.5296/bms.v5i2.6558 URL: http://dx.doi.org/10.5296/bms.v5i2.6558

\begin{abstract}
In order to strengthen their competitiveness, companies have to look for ways that allow them to be innovative and to achieve better performance. To reach these objectives, previous researches suggested that companies must implement motivational managerial practices. In particular, employee empowerment is recognized as a key for building trustful-relationships in the organizations, which in turn lead to innovation and higher level of performance. In this perspective, the purpose of this paper is to examine the effect of employee empowerment on both innovation and organizational performance and to explore the mediating role of trust in these relationships. The main result of the empirical study conducted with a sample of 248 firms belonging to ICT Tunisian sector is that employee empowerment has a positive effect on trust, innovation and organizational performance.
\end{abstract}


Keywords: Empowerment, Trust, Exploratory innovation, Exploitative innovation, Organizational performance 


\section{Introduction}

In today's turbulent environment, organizations increasingly need to develop their innovation capability and performance in order to survive and improve their competitive advantage. In this perspective, many researchers have widely recognized innovation as one of the most important factors of survival and success (Drucker, 1985; Nonaka and Takeuchi, 1995). Therefore, companies are called to search for ways to strengthen their innovation processes. The recent literature on the topic of innovation suggests that this concept should not be considered as a simple result but as a process of learning and development of knowledge and skills (Jansen et al., 2006; Nonaka and Takeuchi, 1995). The definition of innovation has evolved to include dynamic organizational capabilities that forge this process. In this sense, innovation is defined as a process of exploitation of existing capabilities or exploration of new ones (Benner et Tushman, 2003; March, 1991).

Thus, managers must create an organizational climate that promotes the development of capabilities required to innovate. The management literature reported that some managerial practices support capabilities development and have a positive effect on innovation and organizational performance. In particular, researchers pointed out that employee empowerment is a key factor for innovation (Brunetto and Farr-Wharton, 2007; Ertürk, 2012; Fernandez and Moldogaziev, 2013). This practice motivates employees to share their innovative ideas and use their skills in order to contribute to the companies' success.

In fact, the influence of employee empowerment on innovation is still debated. Indeed, a review of the literature on these topics shows that empirical researches which analyzed the relationship between these variables remain controversial. Some researchers reported a positive link between empowerment and innovation (Çakar and Ertürk, 2010; Ertürk, 2012; Helms, 2006; Muindi, 2011). Others found a negative relationship or instead no significant link between these variables. In a research conducted by Kmieciak et al. (2012), it was concluded that empowerment did not affected the company's ability to innovate. Jung et al. (2003)'s study revealed that this managerial practice has a negative effect on organizational innovation. In the light of such controversial results, it could be interesting to identify variables that may mediate or moderate the relationship between employee empowerment and innovation. In this context, Brunetto and Farr-Wharton (2007) argued that empowerment strengthens organizational trust. Ellonen et al. (2008) and Golipour et al. (2011) demonstrated for their part that organizational trust is an important parameter of innovation. Therefore, these authors suggested that trust could be a mediating variable between employee empowerment and innovation.

Moreover, several authors claimed that employee empowerment leads to a better organizational performance (Davis et al., 2000; Meyerson, 2012). Nyhan (1999) noted that this managerial practice is a critical variable for building trustful-relationships in the organizations, which in turn have a positive effect on organizational performance (Davis et al., 2000). In this perspective, trust may also acts as a mediator between empowerment and organizational performance. 
The purpose of this paper is to develop a research model highlighting the relationships between empowerment, trust, innovation and organizational performance and to test empirically this model within the Tunisian Information and Communication Technologies (ICT) sector.

We structure this research as follows. Through a literature review, we highlight the relationship between employee empowerment, trust, innovation and organizational performance and we formulate a serial of hypotheses. Then, we present the methodology adopted in our empirical study. The final part of this paper reports the obtained results. Subsequently, on the basis of these findings, we provide the managerial implications, the main limitations and the future perspectives of our study.

\section{Literature Review}

\subsection{Trust}

Large attention has been assigned to the topic of trust in the sociological, philosophical and managerial literature. An analysis of this literature suggests that proposed definitions for the concept of trust include different aspects. Thus, some authors like Rousseau et al. (1998) defined trust as a "positive attitude toward others", which emerges from social relations. On the basis of an evaluation of the values of another person, an individual will trust or not him. According to Bories (2007), trust is based on assessment of integrity, credibility and benevolence of a person. For this author, it is "a global evaluation composed of assumptions and beliefs, which changed over time, as regards to the credibility and benevolence of the other person, which incites or not to rely on him in situations of uncertainty".

For other researchers, trust involves risk and is based on an expectation of appropriate behavior of others (Barzoki et al., 2013; Bigley et al., 2009; Rousseau et al., 1998; Semerciöz et al., 2011). In this perspective, they associated this concept with the 'vulnerability' of a person who takes a risk by relying on another person (Bigley et al., 2009). For Nooteboom et al., (1997), trust is based on the expectation that the other party will not have an 'opportunistic' behavior. Cook and Wall (1980) noted that the definition of trust integrates two aspects: «faith in the trustworthy intentions of others and confidence in their ability, yielding ascriptions of capability and reliability».

Moreover, different types of trust have been identified in the literature. McAllister (1995) distinguished between cognitive trust and emotional trust. Cognitive trust is based on a rational evaluation of the reasons that justify the choice of relying on a person such as integrity and credibility. Affective trust is determined by emotional links and attachment to the other party.

Otherwise, other forms of trust were distinguished namely lateral trust and vertical trust. Lateral trust characterizes the relationship between co-workers (Barzoki et al., 2013). Vertical trust refers to the relationship between subordinates and superiors (Barzoki et al., 2013). In particular, Costigan et al. (2010) emphasized that it is important to distinguish between 
employees' trust in their immediate supervisors and in the top managers. Employees' trust in their immediate supervisors is formed by a direct relationship while trust in top manager « $i s$ based more on reputation of the organization's top leadership » (Costigan et al., 2010).

In this research, we focus on these three forms of trust namely employees' trust in their co-workers, in their immediate superiors and in top managers of the company.

\subsection{Antecedent of Trust: Employee Empowerment}

In a managerial perspective, empowerment refers to a management style that values autonomy, initiative, decentralization of power and responsibility of employees. It is a practice of strategic management that partially delegates the power to employees, gives them more freedom to accomplish their tasks (Randolph, 1995) and makes them responsible for the results of their actions. Jafari and Iranzadeh, (2013) claimed that employee, who makes self-determined choice about his day to day activities, tends to be more effective and efficient than non-empowered employee.

A review of the literature shows that there are two perspectives to define empowerment: a structural perspective and a psychological perspective. From a structural perspective, empowerment refers to the different organizational practices and policies implemented by leaders to share power and to encourage autonomy and responsibility of employees (Tremblay and Simard, 2005). Bowen and Lawler (1992) associated this variable with management practices that integrate the sharing of knowledge and the decision-making power with employees. From a psychological perspective, empowerment is defined as a psychological state that is linked to "increased intrinsic task motivation" based on an employee's sense of self-determination, meaning, impact and competence (Thomas and Velthouse, 1990). Employees themselves must be convinced that they have the power to act and to perform a task (Tremblay and Simard, 2005). In this research and according to Nyhan (2000) and Kahreh et al. (2011), empowerment is understood as the freedom and the authority given to the employees to perform and control their tasks to the best of their abilities.

Several researches emphasized the relationship between different management practices and trust. In this paper, we investigate the effect of one of these practices namely the empowerment, on organizational trust.

On the one hand, empowerment is understood by numerous researchers as a variable that positively influences employees' trust. According to Khan (1997), empowerment enhances trust between employees and managers. Nyhan (2000) provided also that empowerment contributes to the development of interpersonal trust especially between employees and supervisors. Amara and Bietry (2008) showed furthermore that there is a significant relationship between empowerment and employees' trust in their colleagues, in their superiors and in organization. Henkin and Moye (2006) emphasized also that empowerment is perceived by employees as a sign that their managers trust them. According to these authors, this would lead them in turn to trust their managers. 
Therefore, all the mechanisms aimed to value employees such as empowerment, understood as positive perspectives of managers and immediate supervisors towards them, are likely to build an atmosphere of trust in the organization. In addition, when managers encourage empowerment, they give employees the opportunity to solve problems by themselves. This improves their satisfaction and organizational commitment (Bartram and Casimir, 2007) and develops their trust in the organization.

Thus, this study aims to examine the following hypothesis:

Hypothesis 1: Empowerment has a positive effect on trust.

\subsection{Consequences of Trust: Innovation and Organizational Performance}

\subsubsection{Trust as a Driver for Innovation}

Innovation has been conceptualized in numerous approaches. The review of the existing researches on innovation suggests that the conception of this construct has changed. It is no longer regarded as a result of individual intelligence as was suggested by Schumpeter (1999), but as a result of organizational learning and collective intelligence. In addition, innovation is no longer treated just as a new result but as a process of learning and management of knowledge and competencies (March, 1991; Nonaka and Takeuchi, 1995).

March (1991) distinguished between two types of innovations: exploitative innovation and exploratory innovation. He pointed out that exploitative innovation emerges as the fruit of refinement and extension of existing knowledge and competencies. Moreover, companies may also seek new competencies and experiment with new alternatives which can lead them to an exploratory innovation (March, 1991). According to Jansen et al. (2006), "while exploratory innovation is radical innovation which meets the needs of new customers or markets, exploitative innovation is incremental innovation which is intended to existing customers or markets".

Benner and Tushman (2003) pointed out that, nowadays, business survival depends on a combination between these two types of innovation. They argued that 'ambidextrous' companies are the most successful companies. These companies incorporate a dynamic of continuous innovation based on existing competencies in the past and on new ones.

Clegg et al. (2000) reported that trust has an impact both on generation and implementation of new ideas. According to these researchers, employees do not accept the risk to share their knowledge with others if they not trust them. Golipour et al. (2011) provided also that trust is essential to promote social interactions between organization's members which allow them to access to greater sources of information. Moreover, these authors suggested that employees' trust in their superiors makes them more motivated and more willing to take initiatives and to develop new ideas. Through an empirical study within Tehran Oil Refinery Companies, Golipour et al., (2011) found that trust in supervisors affects significantly company's innovativeness. They found however that co-workers trust or lateral trust has no significant effect on company's innovativeness. Through an empirical study within a sample of 
multinational companies, Ellonen et al. (2008) concluded also that co-workers trust and trust towards leaders have a positive effect on firm's innovative capacity.

Murphy (2002) insisted that social interactions cannot develop in the absence of trust between employees. Abrams et al. (2003) pointed out that trust is the basis of creation and sharing of tacit knowledge which is presented as driver of innovation (Hall and Andriani, 2003). In Semerciöz et al. (2011)'s study, findings suggest also that coworkers trust, trust in immediate supervisors and trust in organization are positively related to organizational innovation.

Thus, we predict that:

Hypothesis 2: Trust has a positive effect on innovation.

\subsubsection{Trust as a Driver for Organizational Performance}

A major challenge for organizations is to seek critical factors that allow them to improve their organizational performance. Despite a rich literature on organizational performance, controversies persist concerning the delimitation of its definition and measurement.

Organizational performance can be defined as "the degree to which companies achieved their business objectives" (Janepuengporn and Ussahawanitchakit, 2011). This construct is assessed essentially through financial indicators (such as profit, return on investment) or non-financial indicators (such as customer satisfaction and quality of products and services). Deshpande et al. (1993) and Drew (1997) developed pertinent measure of organizational performance that integrates both financial and non-financial indicators. It refers according to them "the degree of overall success, market share, growth rate, profitability and innovativeness in comparison with key competitors".

In fact, several researches highlighted that trust is a key factor for organizational performance (Davis et al., 2000; Koohang and Paliszkiewicz, 2013; Mayer and Gavin, 2005). Indeed, trust is a vital ingredient for collaborative climate (Murphy, 2002). It fosters knowledge sharing and stimulates creative behavior (Sankowska, 2013). According to Awamleh (2013), trust has a positive influence on employee commitment towards the company and on their satisfaction and performance. Davis et al. (2000) suggested that a trustful relationship between employees and top managers contributes to superior organizational performance. Shockley-Zalabak et al., (2000) demonstrated that trust in top managers and trust in immediate superiors are critical variables in achieving organizational effectiveness. However, Paliszkiewicz (2011) claimed that a low-trust organizational culture can leads to negative economic consequences.

Thus, we predict that:

Hypothesis 3: Trust has a positive effect on organizational performance. 


\subsection{Mediating Effect of Trust}

\subsubsection{Empowerment and Innovation: Mediating Effect of Trust}

Many authors have sought to identify management practices that build an organizational climate promoting innovation. Some of them argue that management styles incorporating empowerment allow employees to have more autonomy, authority and responsibility and promote innovation.

Indeed, empowerment has a positive impact on employees and in particular on their ability to innovate. Çakar and Ertürk (2010), Ertürk (2012), Khodabakhshi et al. (2013), Knight-Turvey (2006) and Spreitzer (1995) provided evidence that employee empowerment is a significant predictor of innovation. Through empirical studies they conducted in the industrial sector, Ertürk (2012) and Spreitzer (1995) concluded that empowerment leads to innovative behaviors. This practice encourages the autonomy and initiative of employees and makes them more willing to provide more efforts. Due to the flexibility left to them, they are more motivated especially to explore new ways of doing thinks and to generate multiple ideas which can lead in particular to exploratory innovations. The same idea has been advocated by Wang (2012) who pointed out that empowerment increases employees' creativity and initiative. Hasan and Thamizhmanii (2010) stated also that empowerment increases collaboration which boosts innovation.

According to Tremblay et al. (2000) "an empowerment culture, encourages employees to feel more important, responsible and free to use their intelligence and competences". This practice allows therefore companies to exploit employees' knowledge and competencies. Khodabakhshi et al. (2013) argued that empowerment mediates the relationship between knowledge management and innovation.

Thus, we propose to test the following hypothesis:

Hypothesis 4: Empowerment has a positive effect on innovation.

From the researches that we analyzed above, empowerment appears as a determinant of employees' trust, which in turns boosts innovation. Thus, trust could be a mediating variable that explains the indirect link between the empowerment and innovation. In particular, Brunetto and Farr-Wharton (2007) noted that empowerment has a positive impact on trust, which is a key factor for innovation.

Therefore, we can state the following hypothesis:

Hypothesis 5: Trust mediates the relationship between empowerment and innovation.

\subsubsection{Empowerment and Organizational Performance: Mediating Effect of Trust}

A review of literature indicates that organizational performance is influenced by three critical factors. Internal motivation, firm's external environment and organizational capacity drive organizational performance (Lusthaus et al., 2002). In this paper, we focus on one of these 
drivers factors namely internal motivation. Indeed, leaders should adopt managerial practices such as employee empowerment that motivate them in order to make more efforts and assist organizations to achieve its objectives. This motivational technique enhances employees feeling of personal achievement. It gives them the opportunity to have meaningful work in which they can use their knowledge and competencies in an optimal manner (Naderi et al., 2008). Thus, employees' empowerment can improve their individual performance which in turn will contribute to organizational performance (Awamleh, 2013). The same idea was claimed by Greasley et al. (2005). Dobre (2013) suggested that empowerment enhances employees' satisfaction and motivation and contributes to better organizational productivity, customer satisfaction and better profits. Meyerson (2012) noted that "employee empowerment is a motivational technique that is designed to improve performance if managed properly through increased levels of employee's participation and self-determination". In addition, $\mathrm{Ke}$ and Zheng (2010) provided evidence that employee empowerment is a foundation of continuous improvement and enables better organizational performance.

Thus, we predict that there is a direct relationship between empowerment and organizational performance:

Hypothesis 6: Empowerment has a positive effect on organizational performance.

Moreover, as mentioned above, several studies emphasized the role of employee empowerment as driver for trust, which in turn has a positive effect on organizational performance. In this perspective, the effect of empowerment on organizational performance could be mediated by trust. Hence, we can state the following hypothesis:

Hypothesis 7: Trust mediates the relationship between empowerment and organizational performance.

\subsection{Contributions of Innovation to Organizational Performance}

Companies' resources are considered as key factors of organizational performance. Among these resources, innovation contributes to the enrichment of companies and to higher levels of organizational performance (Cingoz et Akdogan, 2011; Hooley et al., 1998; Walker, 2004). In this perspective, several studies emphasized that innovation is significantly and positively associated with firms' performance (Gunday et al., 2011; Vincent et al., 2004). Indeed, innovation companies are able to create a sustainable competitive advantage in the marketplace, which in turn has a catalytic effect on organizational performance (Vincent et al., 2004). Moreover, Gunday et al., (2009) provided evidence that different types of innovation (organizational, process, product and marketing innovations) have positive effects on different aspects of companies' performance namely market, production, innovative and financial performance. Furthermore, Gopalakrishnan (2000) claimed that the speed of adoption of innovations has a positive impact on firm's performance.

In fact, the influence of innovation on organizational performance is still debated. A review of numerous researches shows that this relationship remains controversial. Indeed, some studies 
provided evidence that innovation has a positive effect on organizational performance (Bierly and Chakrabarti, 1996; Caves and Ghemawat, 1992; Darroch, 2005; Matsuo, 2006). However, others found negative relationship (Balkin et al., 2000) or instead no significant relationship between these variables (Greve, 2003). Therefore, the relationship between innovation and organizational performance appears to be complex because of the lack of consensus relating the effect of the one on the other.

Hence, we pose this following hypothesis:

Hypothesis 8: Innovation has a positive effect on organizational performance.

\subsection{Presentation of the Conceptual Model}

In this research, we analyze the effect of empowerment on trust, which in turn contributes to innovation and organizational performance. On the bases of theoretical debates synthesized, we developed the following research model (Figure 1):

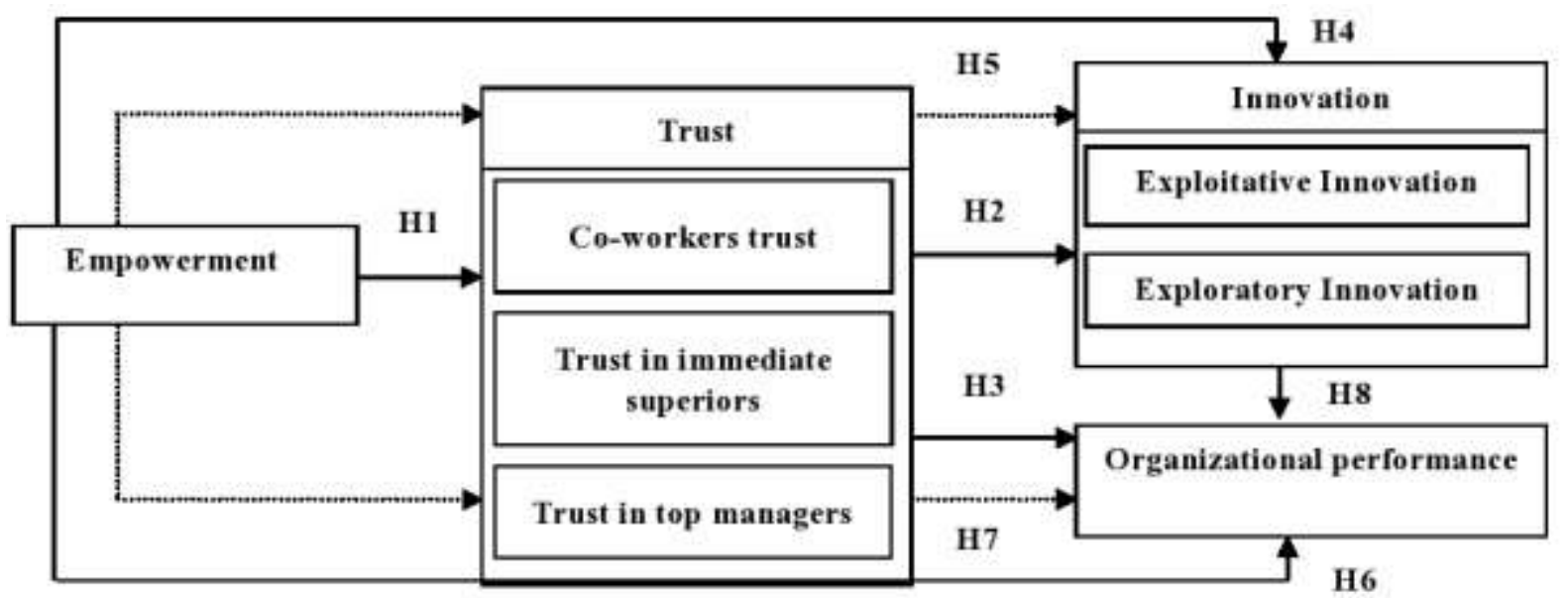

\section{Direct link}

Indirect link

Figure 1. Theoretical model

This theoretical model was tested on a sample of ICT Tunisian companies.

\section{Empirical Study}

\subsection{Research Methodology}

Survey data was obtained from Tunisian companies belonging to the information and communication technologies (ICT) sector. To find answers to our problems and test our conceptual model, we adopted a quantitative approach conducted through the administration of a questionnaire in paper form. We sent out 300 questionnaires. The final sample obtained contained 248 employees. The response rate to the questionnaire was nearly $82 \%$. 
$42 \%$ of respondents have an experience of over 5 years in the companies in which they work. $91 \%$ of them are graduates of higher education. The majority of them was males (64\%) and belongs to small and medium enterprises (SMEs) (88\%). The sample is therefore homogeneous compared to the basic population which is composed mostly of SMEs.

The research variables were operationalized using existing scales in the management literature. Thus, the empowerment (4 items) was measured through Nyhan's (2000) scale. Co-workers trust and trust in top managers were each operationalized by six items developed by Cook and Wall (1980). Trust in immediate superiors was measured by eight items conceptualized by Nyhan and Marlowe (1997). Exploratory and exploitative innovations were measured by Jansen et al.'s (2006) scale which contains 12 items (6 items for each type of innovation). For organizational performance, we adopt measurement scale of Deshpande et al. (1993) and Drew (1997) which contains 6 items. For all items, we used a five point Likert scale $(1=$ strongly disagree; 5 = strongly agree $)$.

\subsection{Measurement Assessment of Variables}

Through the SPSS 16.0 software, we performed principal component analysis with varimax rotation in order to determine the number of valid items for each scale measuring variables of our research. We deleted items with factor loading values less than 0.5. Then, we used the Cronbach's alpha to estimate internal reliability for scales. This coefficient values exceeded the level of 0.70 recommended by Nunnaly and Bernstein (1994) for all variables (see Table1). We can therefore conclude that items are reliably measuring variables. Normality of data was also assessed by using the Skewness and Kurtosis coefficients.

We conducted also confirmatory factor analysis using the AMOS 16.0 software. First, we examined the most relevant fit indices of the measurement models recommended by $\mathrm{Hu}$ and Bentler (1999) and Chin and Todd (1995). In this perspective, we verified that the ratio between the Chi-Square value and the degrees of freedom $(\chi 2 / \mathrm{df})$ value is less than 3 and that the Goodness-of-fit index (GFI) value is greater than 0.9. In addition, we established that a Comparative Fit Index (CFI) value is greater than 0.95 and that a Root Mean Square Error of Approximation (RMSEA) value is less than 0.06. Thus, we concluded that all fit indices were quite satisfactory.

Moreover, the reliability of each scale was tested by checking if the Jöreskog Rhôs index is above 0.7 (Fornell and Larcker, 1981). Findings highlighted in Table 1, reveal that internal consistency of each scale was confirmed. Then, we tested the convergent validity of the scales, ensuring that the value of the rhôs of convergent validity ( $\rho v c)$ for each scale is greater than 0.5 (Fornell and Larcker, 1981). Results show that convergent validity is verified for all measurement scales. Finally, discriminant validity was assessed by comparing the average variance extracted and squared correlations between the variables in pairs (Fornell and Larcker, 1981). In this perspective, we find that the squared correlations between each pair of variables tested are less than the average variance extracted. Discriminant validity is thus confirmed. The final structure of the scales measuring our research variables is presented in 
Table 1 below:

Table 1. Reliability and convergent validity of measurement instruments

\begin{tabular}{|l|c|c|c|c|c|}
\hline Variables & $\begin{array}{c}\text { Number } \\
\text { of items }\end{array}$ & $\begin{array}{c}\text { Percentage of } \\
\text { variance explained }\end{array}$ & $\begin{array}{c}\text { Cronbach's } \\
\text { Alpha }\end{array}$ & $\begin{array}{c}\text { Jôreskog's } \\
\text { Rhôs }\end{array}$ & $\begin{array}{c}\text { Rhô of } \\
\text { convergent } \\
\text { validity }\end{array}$ \\
\hline Empowerment & 4 & $86.410 \%$ & 0.947 & 0.929 & 0.768 \\
\hline Co-workers Trust & 4 & $69.657 \%$ & 0.854 & 0.912 & 0.724 \\
\hline $\begin{array}{l}\text { Trust in immediate } \\
\text { supervisors }\end{array}$ & 5 & $83.175 \%$ & 0.948 & 0.941 & 0.764 \\
\hline Trust in top managers & 4 & $74.691 \%$ & 0.884 & 0.897 & 0.691 \\
\hline Exploitative innovation & 5 & $79.242 \%$ & 0.927 & 0.963 & 0.842 \\
\hline Exploratory innovation & 5 & $69.740 \%$ & 0.879 & 0.835 & 0.660 \\
\hline Organizational performance & 5 & $77.950 \%$ & 0.924 & 0.932 & 0.751 \\
\hline
\end{tabular}

\subsection{Results}

Structural equation modeling (SEM) was performed to test our research hypothesis by using AMOS 16. In particular, maximum likelihood method and a bootstrap procedure with 200 iterations were applied. A four-step approach based on Baron and Kenny (1986) complemented by relevant contributions of Preacher and Hayes (2008) who treated multiple mediation models, was used to test the mediating role of trust. First, a direct link between the independent variables and each dependent variable must be demonstrated. Then, the dependent variables should have positive effects on each mediating variable. Moreover, the third phase is to assess whether mediating variables have a positive effects on each dependent variable in a model incorporating all the variables of the research. If these three conditions are satisfied, mediation is confirmed. Finally, the last step is to examine the total or partial nature of mediation and to verify its significance using the Sobel test. Mediation is complete if the regression coefficient linking the independent variable and the dependent variable is canceled when we incorporate into the model the mediating variable.

First, full model adjustment was assessed by examining the most useful fit indices with reference to the recommendations of Chin and Todd (1995) and Bentler and Hu (1999). The results from SEM show that the model fits the data satisfactorily. In fact, chi-square/degree of freedom value (1.731) is less than 3 (Chin and Todd, 1995). GFI score (0.966) is superior to 0.9 , CFI value (0.987) is greater than 0.95 and RMSEA value (0.059) is less than 0.06 as recommended by $\mathrm{Hu}$ and Bentler (1999).

Next, we attempted to clarify the relationships between research's variables following the four-step method developed by Baron and Kenny (1986).

Results highlighted in Table 2 reveal a significant direct relationship between empowerment and respectively co-workers trust $(\beta=0.237, p<0.001)$, trust in immediate supervisors $(\beta=0.434, p<0.001)$ and trust in top managers $(\beta=0.214, p<0.001)$. Hypothesis 1 is thus confirmed.

Moreover, co-workers trust $(\beta=0.377, \mathrm{p}<0.001)$ and trust in immediate supervisors $(\beta=0.134$, 
$\mathrm{p}<0.01)$ are significantly and positively related to exploitative innovation. However, this type of innovation is not predicted by trust in top managers. Exploratory innovation is related to trust in immediate supervisors $(\beta=0.202, p<0.001)$. But, trust in co-workers and trust in top managers are not positively associated with exploratory innovation. Hence, hypothesis 2 is partially confirmed.

Co-workers trust $(\beta=0.227, p<0.001)$ and trust in immediate supervisors $(\beta=0.185, p<0.001)$ have also a positive impact on organizational performance, which in turn is not predicted by trust in top managers. Hypothesis $\mathrm{H} 3$ is therefore partially supported.

In addition, findings allow us to conclude that empowerment is positively correlated to exploitative innovation $(\beta=0.295, \mathrm{p}<0.001)$, exploratory innovation $(\beta=0.509, \mathrm{p}<0.001)$ and organizational performance $(\beta=0.271, p<0.001)$. These results confirms hypothesis $\mathrm{H} 4$ and H6.

Finally, both exploratory $(\beta=0.175, p<0.01)$ and exploitative innovations $(\beta=0.507, p<0.001)$ have a positive and significant effects on organizational performance. Hypothesis $\mathrm{H} 8$ is thus supported.

Table 2. Path analysis results

\begin{tabular}{|c|c|c|c|c|c|}
\hline Hypotheses & Independent variable & Dependent variable & $\beta$ & C.R. & $\mathbf{P}$ \\
\hline \multirow{3}{*}{ H1 } & Empowerment & Co-workers trust & 0.237 & 3.516 & $* * *$ \\
\hline & Empowerment & Trust in immediate supervisors & 0.434 & 6.632 & $* * *$ \\
\hline & Empowerment & Trust in top managers & 0.214 & 3.314 & $* * *$ \\
\hline \multirow{6}{*}{$\mathbf{H 2}$} & Co-workers trust & Exploitative Innovation & 0.377 & 5.663 & $* * *$ \\
\hline & Co-workers trust & Exploratory Innovation & 0.044 & 0.993 & 0.321 \\
\hline & Trust in immediate supervisors & Exploitative Innovation & 0.134 & 1.986 & 0.002 \\
\hline & Trust in immediate supervisors & Exploratory Innovation & 0.202 & 3.241 & $* * *$ \\
\hline & Trust in top managers & Exploitative Innovation & 0.041 & 0.894 & 0.372 \\
\hline & Trust in top managers & Exploratory Innovation & 0.029 & 1.071 & 0.284 \\
\hline \multirow{3}{*}{$\mathbf{H 3}$} & Co-workers trust & \multirow{3}{*}{ Organizational performance } & 0.227 & 2.963 & 0.004 \\
\hline & Trust in immediate supervisors & & 0.185 & 2.563 & $* * *$ \\
\hline & Trust in top managers & & 0.021 & 0.373 & 0.709 \\
\hline \multirow{2}{*}{ H4 } & Empowerment & Exploitative Innovation & 0.295 & 3.790 & $* * *$ \\
\hline & Empowerment & Exploratory Innovation & 0.509 & 8.901 & $* * *$ \\
\hline H6 & Empowerment & Organizational performance & 0.271 & 3.654 & $* * *$ \\
\hline \multirow{2}{*}{ H8 } & Exploitative Innovation & Organizational performance & 0.175 & 2.704 & 0.007 \\
\hline & Exploratory Innovation & Organizational performance & 0.507 & 8.860 & $* * *$ \\
\hline
\end{tabular}

$\beta=$ Standardized estimate, $C . R .=$ critical ratio, $P=$ level of significance, $* * *:$ Significant at $\mathrm{P} \leq$ 0,001

To assess mediation, we examined conditions recommended by Baron and Kenny (1986). In this research, we predicted that trust may mediate the relationship between empowerment and innovation. Results suggest that both co-workers-trust and trust in immediate supervisors mediate the empowerment-exploitative innovation link. Trust in immediate supervisors acts also as a mediator in the relationship between empowerment and exploitative innovation.

Moreover, we predicted also that trust may mediate the link between empowerment and 
organizational performance. Findings confirm that both trust in co-workers and trust in immediate supervisors mediate the empowerment-exploitative innovation relationship.

In fact, results reveal that the relationship between each independent variable and each dependent variable in the full mediation model is significant but has decreased compared to the first model testing the direct causal link between them. The mediating variables reduced the total effect of independent variable (empowerment) on each dependent variable (exploitative innovation, exploratory innovation and organizational performance) by the total of the indirect effect. In this case, the mediating effects operated by the two type of trust (trust in co-workers and trust in immediate supervisors) in the model tested are partial. Finally, we used the Sobel test that confirmed the significance of the mediating effects. Hypotheses 5 and 7 are thus partially confirmed.

Table 3. Significance of indirect effects of mediating variables

\begin{tabular}{|c|c|c|c|c|c|c|}
\hline $\begin{array}{l}\text { Independent } \\
\text { variable }\end{array}$ & $\begin{array}{c}\text { Dependent } \\
\text { variable }\end{array}$ & $\begin{array}{l}\text { Mediating } \\
\text { variable }\end{array}$ & $\begin{array}{l}\text { Indirect } \\
\text { Effect }\end{array}$ & $\begin{array}{c}\text { Total indirect } \\
\text { effect }\end{array}$ & $\begin{array}{l}\text { Total } \\
\text { effect }\end{array}$ & Sobel test \\
\hline \multirow[b]{2}{*}{ Empowerment } & \multirow{2}{*}{$\begin{array}{l}\text { Exploitative } \\
\text { innovation }\end{array}$} & $\begin{array}{c}\text { Co-workers } \\
\text { trust }\end{array}$ & 0.089 & \multirow[b]{2}{*}{0.147} & \multirow[b]{2}{*}{0.295} & $\mathrm{z}=4.27 * * *$ \\
\hline & & $\begin{array}{c}\text { Trust in } \\
\text { immediate } \\
\text { supervisors }\end{array}$ & 0.058 & & & $\mathrm{z}=3.31 * * *$ \\
\hline Empowerment & $\begin{array}{l}\text { Exploratory } \\
\text { innovation }\end{array}$ & $\begin{array}{c}\text { Trust in } \\
\text { immediate } \\
\text { supervisors }\end{array}$ & 0.087 & 0.087 & 0.509 & $\mathrm{z}=4,95 * * *$ \\
\hline \multirow{2}{*}{ Empowerment } & \multirow{2}{*}{$\begin{array}{l}\text { Organizational } \\
\text { Performance }\end{array}$} & $\begin{array}{c}\text { Co-workers } \\
\text { trust }\end{array}$ & 0.053 & \multirow{2}{*}{0.176} & \multirow{2}{*}{0.271} & $\mathrm{z}=3.21 * * *$ \\
\hline & & $\begin{array}{c}\text { Trust in } \\
\text { immediate } \\
\text { supervisors }\end{array}$ & 0.080 & & & $\mathrm{z}=4,73 * * *$ \\
\hline
\end{tabular}

*** : Significant at $\mathrm{P} \leq 0,001$

\section{Discussion and Conclusion}

This investigation operated within Tunisian ICT sector allows us to better understand how employee empowerment contributes to innovation. It reveals that this managerial practice increases the level of employees' trust which in turn has a positive effect on innovation and organizational performance. Our results are in accordance with earlier researches conducted in other contexts.

First, our investigation complements previous studies, which provided evidence that 
employee empowerment is an antecedent of employees' trust in their co-workers, in immediate supervisors and in top managers of the companies. These results coincide in the particular with the works of Nyhan (2000) who conducted an empirical study in the public sector in Florida and the study of Bietry and Amara (2008) who tested this relationship in the Tunisian industrial sector. Indeed, for employees, empowerment is a proof of favorable treatment granted to them by their immediate supervisors and top managers. This feeling would lead them in turn to trust their managers and supervisors. Empowerment increase also cooperation between co-workers which permits to build an atmosphere of trust in the organization.

Moreover, our study establishes the existence of a close relationship between trust in immediate supervisors and both exploitative and exploratory innovations. However, trust in top managers has not a significant effect on these two types of innovation. This result could be explained by the fact that employees' relationship with their immediate supervisors is founded on more direct contacts than relationship with top managers. It involves frequent interactions. Furthermore, trust in co-workers is revealed as a key factor only for exploitative innovation. In fact, trust in immediate supervisors is critical to foster employee commitment in the innovation process of the organizations. It boosts employees in order to use their skills and also to explore original ideas and new opportunities. High quality relationships between employees and their supervisors "create feelings of obligation for employees to reciprocate in positive ways, especially on their innovative behavior" (Arora and Kamalanabhan, 2013).

Trust in co-workers and trust in immediate supervisors are also revealed as predictors of organizational performance. This finding partially corroborates the work of Shockley-Zalabak et al., (2000) who demonstrated that trust in immediate supervisors is a critical variable in achieving organizational effectiveness. However, it contradicts with Davis et al. (2000)'s study who suggested that trust in top managers contributes to superior organizational performance.

Then, this work establishes strong evidence regarding the relationship between employee empowerment and innovation. This result is consistent particularly with the works of Spreitzer (1995), Knight-Turvey (2006), Çakar and Ertürk (2010) and Ertürk (2012) who found significant links between empowerment and innovation from empirical investigations conducted in industrial sector. Our findings show that empowerment has not only allowed companies to build innovation from their existing competencies (exploitative innovation) but also by seeking new sources of competencies (exploratory innovation). Results highlight that the effect of empowerment on the exploratory innovation is higher than the exploitative innovation. Indeed, by giving employees the opportunity to be independents, to have more power and participate in decision making, they feel more valued and could be in return more willing to make more efforts and more initiatives. They may experiment new ways of doing think, create new knowledge and generate original ideas that promote exploratory innovation.

Employee empowerment is also revealed as a significant predictor of organizational performance. This result is in the same direction as the work of Ke and Zheng (2010). With 
this motivational practice, employees have the opportunity to use their knowledge and competencies in an optimal manner, which may lead to achievement of better organizational performance.

In addition, findings show that both exploitative and exploratory innovations are strongly associated with improvement of organizational performance. This result is consistent with Gunday et al. (2011) and Vincent et al. (2004). Innovative companies are able to create a sustainable competitive advantage, to be more successful than its competitors and to generate better profits.

Finally, our investigation highlights the partial mediating role of both trust in co-workers and in immediate supervisors in the relationship between employee empowerment and exploitative innovation. In addition, trust in immediate supervisors partially mediates the link empowerment-exploratory innovation. Furthermore, trust in co-workers and in immediate supervisors act as a partially mediators between empowerment and organizational performance. Therefore, more employees will be valued by such managerial practice, more their feeling of trust will be reinforced and motivate them to improve their ability to innovate and to achieve better organizational performance.

This paper provides a theoretical perspective to understand the relationships between employee empowerment, trust, innovation and organizational performance. Moreover, from a practical standpoint, this paper offers an opportunity for managers to better recognize how they can improve innovation and organizational performance. Indeed, managers are expected to promote practices that are valued by employees, influence positively their behaviors and build trustful relationships in the organizations. Implementing employee empowerment will allows managers to create a climate of trust within the organization but also to absorb relevant knowledge and original ideas that can help them in decision making and promote innovation and organizational performance.

This paper contains some limitations. In fact, the main limitation consists of the choice of a non-probabilistic sampling method and the size of the sample which constrain the generalizability of the results. Moreover, innovation and organizational performance vary by sector and by firm size. Therefore, there is a need to refine this study by performing a comparative study between sectors and between firms of different size. Also, it would be interesting to realize a comparative cross-cultural study. In addition, researchers may integrate in the model of this research the different types of innovation. Finally, they may examine the influence of other managerial practices such as performance-based promotion on innovation and organizational performance.

\section{References}

Abrams, L.C., Cross, R., Lesser, E., \& Levin, D.Z. (2003). Nurturing interpersonal trust in knowledge-sharing networks. The Academy of Management Executive, 17(4), 64-77. http://dx.doi.org/10.5465/AME.2003.11851845 
Amara, M. Z., \& Bietry, F. (2008). Le développement de l'implication organisationnelle par la confiance: Application au contexte tunisien. AGRH proceedings, Dakar.

Arora, V., \& Kamalanabhan, T. J. (2013). Linking supervisor and coworker support to employee innovative behavior at work: role of psychological Conditions. Academic and Business Research Institute International Conference proceedings, New Orleans.

Awamleh, N. A. (2013). Enhancing Employees Performance via Empowerment: A Field Survey. Asian Journal of Business Management, 5(3), 313-319.

Balkin, D. B., Markman, G. D., \& Gomez-Mejia, L. R. (2000). Is CEO Pay in high technology firms related to innovation?. Academy of Management Journal, 43(6), 1118-1129. http://dx.doi.org/10.2307/1556340

Baron, R. M., \& Kenny, D. A. (1986). The Moderator-Mediator Variable Distinction in Social Psychological Research: Conceptual, Strategic, and Statistical Considerations. Journal of $\begin{array}{llrl}\text { Penality and Social } & \text { Psychology, } & \text { 51(6), } & \text { 1173-1182. }\end{array}$ http://dx.doi.org/10.1037/0022-3514.51.6.1173

Bartram, T., \& Casimir, G. (2007). The relationship between leadership and follower in role performance and satisfaction with the leaders: the mediating effects of empowerment and trust in the leader. Leadership \& Organization Development Journal, 28(1), 4-19.

Barzoki, A.S., Abzari, M., Mazraeh, S., \& Maleki, S.V. (2013). Determining the Effect of Organization's Structural Dimensions on Organizational Trust in Esfahan's Mobarakeh Steel Company. Journal of Basic and Applied Scientific Research, 3(3), 723-731. http://dx.doi.org/10.1108/01437730710718218

Benner, M., \& Tushman, M. (2003). Exploitation, exploration and process management: the productivity dilemma revisited. Academy of Management Review, 28(2), 238-256.

Bierly, P., \& Chakrabarti, A. (1996). 'Generic knowledge strategies in the US pharmaceutical industry'. Strategic Management Journal, 17 (Winter Special Issue), 123-135.

Bigley, G. A., McAllister, D. J., \& Tan, H. H. (2009). Effects of Interpersonal Trust on Employee Avoidance and Approach Self-Regulation. In G.T. Solomon (Ed.), Academy of Management Best Papers Proceedings.

Bories, D. (2007). La confiance dans les relations acheteurs vendeurs : le rôle modérateur du cycle de vie relationnel. 6th International Marketing Trends Conference. 26-27 January 2007, Paris.

Bowen, D. E., \& Lawler, E. E. (1992). The Empowerment of Service Workers: What, Why, How and When. Sloan Management Review, 33(3), 31-39.

Brunetto, Y., \& Farr-Wharton, R. (2007). The moderating role of trust in SME owner/managers decision-making about collaboration. Journal of Small Business Management, 45(3), 362-387. http://dx.doi.org/10.1111/j.1540-627X.2007.00218.x 
Çakar, N. D., \& Ertürk, A. (2010). Comparing innovation capability of small and medium-sized enterprises, examining the effects of organizational and empowerment. Journal of Small Business Management, 48(3), 325-559. http://dx.doi.org/10.1111/j.1540-627X.2010.00297.x

Caves, R., \& Ghemawat, P. (1992). Identifying mobility barriers. Strategic Management Journal, 13, 1-12. http://dx.doi.org/10.1002/smj.4250130102

Chin, W. W., \& Todd, P. A. (1995). On the Use, Usefulness, and Ease of Use of Structural Equation Modeling in MIS Research: A Note of Caution. MIS Quarterly, 19(2), 237-246. http://dx.doi.org/10.2307/249690

Cingöz, A., \& Akdoğan, A.A. (2011). An empirical examination of performance and image outcome expectation as determinants of innovative behavior in the workplace. Procedia-Social and Behavioral Sciences, $24, \quad 847-853$. http://dx.doi.org/10.1016/j.sbspro.2011.09.099

Clegg, C., Unsworth, K., Epitropaki, O., \& Parker, G. (2002). Implicating trust in the innovation process. Journal of Occupational and Organizational Psychology, 75(4), 409-422. http://dx.doi.org/10.1348/096317902321119574

Cook, J., \& Wall, T. (1980). New work attitude measures of trust, organizational commitment and personal need non-fulfilment. Journal of Occupational Psychology, 53(1), 39-52. http://dx.doi.org/10.1111/j.2044-8325.1980.tb00005.x

Costigan, R., Ilter, S., \& Berman, J. (1998). A multi-dimensional study of trust in Organizations. Journal of Managerial Issues, 10, 303-317.

Darroch, J. (2005). Knowledge management, innovation and firm performance. Journal of Knowledge Management, 9(3), 101-115. http://dx.doi.org/10.1108/13673270510602809

Davis, J., Schoorman, F. D., Mayer, R., \& Tan, H. (2000). Trusted unit manager and business unit performance: Empirical evidence of a competitive advantage. Strategic Management, $21(1)$ 563-576. http://dx.doi.org/10.1002/(SICI)1097-0266(200005)21:5<563::AID-SMJ99>3.0.CO;2-0

Deshpande, R., Jarley, U., \& Webster, F. (1993). Corporate culture, customer orientation, and innovativeness in Japanese firms: A quadrant analysis. Journal of Marketing, 57, 23-37. http://dx.doi.org/10.2307/1252055

Dobre, O. I. (2013). Employee motivation and organizational performance. Review of Applied Socio- Economic Research, 5(1), 53-60.

Drew, S. (1997). From knowledge to action: the impact of benchmarking on organizational performance. Long Range Planning, 30(3), 427-441. http://dx.doi.org/10.1016/S0024-6301(97)90262-4

Drucker, P. F. (1985). Innovation and Entrepreneurship: practice and principle. Harper \& 
Row (Eds), New York.

Ellonen, R., Blomqvist, K., \& Puumalainen, K. (2008). The role of trust in organizational innovativeness. European Journal of Innovation Management, 11(2), 160-181. http://dx.doi.org/10.1108/14601060810869848

Ertürk, A. (2012). Linking Psychological Empowerment to Innovation Capability: Investigating the moderating Effect of Supervisory Trust. International Journal of Business and Social Science, 3(14), 153-165.

Fernandez, S., \& Moldogaziev, T. (2013). Using employee empowerment to encourage Innovative behavior in the public sector. Journal of Public Administration Research and Theory, 23(1), 155-187. http://dx.doi.org/10.1093/jopart/mus008

Fornell, C., \& Larker, D. F. (1981). Evaluating structural equations models with unobservable variables and measurement error. Journal of Marketing Research, 18, 39-50. http://dx.doi.org/10.2307/3151312

Golipour, R., Gholamreza, J., Mirzaei, M. A., \& Roshandel, A. T. (2011). The impact of organizational trust on innovativeness at the Tehran oil refinery company African. Journal of business Management, 5(7), 2660-2667.

Gopalakrishnan, S. (2000). Unraveling the links between dimensions of innovation and organizational performance.The Journal of High Technology Management Research, 11(1), 137-153. http://dx.doi.org/10.1016/S1047-8310(00)00024-9

Greasley, K., Bryman, A., Dainty, A., Price, A., Soetanto, R., \& King, N. (2005). Employee perceptions of empowerment. Employee Relations, 27(4), 354-368. http://dx.doi.org/10.1108/01425450510605697

Greve, H. R. (2003). A behavioral theory Of Rand D Expenditures and innovations: evidence from shipbuilding. Academy of Management Journal, 46(6), 685. http://dx.doi.org/10.2307/30040661

Günday, G., Ulusoy, G., Kılıç, K., \& Alpkan, L. (2011). Effects of innovation types on firm performance. International Journal of Production Economics, 133(2), 662-676. http://dx.doi.org/10.1016/j.ijpe.2011.05.014

Hall, R., \& Andriani, P. (2003). Managing knowledge associated with innovation. Journal of Business Research, 56, 145-52. http://dx.doi.org/10.1016/S0148-2963(01)00287-9

Helms, M. M. (2006). Encyclopedia of management (5th ed.). Thomson Gale, USA.

Henkin, A. B., \& Moye, M. J. (2006). Exploring associations between employee empowerment and interpersonal trust in managers. Journal of Management Development, 25(2), 101-117. http://dx.doi.org/10.1108/02621710610645108

Hooley, G., Broderick, A., \& Möller, K. (1998). Competitive positioning and the 
resource-based view of the firm. Journal of Strategic Marketing, 6(2), 97-116. http://dx.doi.org/10.1080/09652549800000003

Hu, L.T., \& Bentler, P. M. (1999). Cutoff criteria for fit indexes in covariance structure analysis: Coventional criteria versus new alternatives, Structural Equation Modeling, 6(1), 1-55. http://dx.doi.org/10.1080/10705519909540118

Jafari, S., \& Iranzade, I. (2013). The Relationship between Empowerment and Organizational Citizenship Behavior. International Journal of Basic Sciences \& Applied Research, 2(10), 903-907.

Janepuengporn, K., \& Ussahawanitchakit, P. (2011). The impacts of knowledge management strategy on organizational performance: an empirical study of clothing manufacturing businesses in Thailand. International Journal of Business Strategy, 11(1), 92-109.

Jansen, J. J.., Van Den Bosch, F. A. J., \& Volberda, H. W. (2006). Exploratory innovation, exploitative innovation, and performance effects of organizational antecedents and environmental moderators. Management Science, 52(1), 1661-1674. http://dx.doi.org/10.1287/mnsc.1060.0576

Jung, D. I., Chow, C., \& Wu, A. (2003). The role of transformational leadership in enhancing organizational innovation: Hypotheses and some preliminary findings. The Leadership Quarterly, 14(4/5), 525-544. http://dx.doi.org/10.1016/S1048-9843(03)00050-X

Kahreh, M. S., Ahmadi, H., \& Hashemi, A. (2011). Achieving Competitive Advantage Through Empowering Employees: An Empirical Study. Far East Journal of Psychology and Business, 3(2), 26-37.

Ke, W., \& Zhang, P. (2011). Effects of Empowerment on Performance in Open-Source Software Projects. IEEE Transactions On Engineering Management, 58(2), 334-346. http://dx.doi.org/10.1109/TEM.2010.2096510

Khan, S. (1997). The key to being a leader company: empowerment. Journal for Quality \& Participation, 20, 44-50.

Khodabakhshi, F., Sajad, N. K., \& Shiargar, M. (). The Impact of Knowledge management on Innovation with the mediating role of empowerment. Life Science Journal, 10(2), 1385-1390.

Kmieciak, R., Michna, A., \& Meczynska, A. (2012). Innovativeness, empowerment and IT capability: evidence from SMEs. Industrial Management and Data Systems, 112(5), 707-728. http://dx.doi.org/10.1108/02635571211232280

Knight-Turvey, N. (2006). Influencing employee innovation through structural empowerment initiatives: The need to feel empowered. Entrepreneurship Theory and Practice, 313-324.

Koohang, A., \& Paliszkiewicz, J. (2013). Knowledge construction in e-learning: An empirical validation of an active learning model. The Journal of Computer Information Systems, 53(3), 109-114. 
Lusthaus, C., Adrien, M. H., Anderson, G., Carden, F., \& Montalvan, G. P. (2002). Organizational assessment: a framework for improving performance. Ottawa: International Development Research Centre/Inter-American Development Bank.

March, J. G. (1991). Exploration and exploitation in organizational learning. Organization Science, 2(1), 71-87. http://dx.doi.org/10.1287/orsc.2.1.71

Matsuo, M., (2006). Customer orientation, conflict, and innovativeness in Japanese sales departments. Journal of Business Research, 59, 242-250. http://dx.doi.org/10.1016/j.jbusres.2005.06.002

Mayer, R.C., \& Gavin, M.B. (2005). Trust in management and performance: Who minds the shop while the employees watch the boss?. Academy of Management Journal, 48(5), 874-888. http://dx.doi.org/10.5465/AMJ.2005.18803928

McAllister, D. J. (1995). Affect and cognition-based trust as foundations for interpersonal cooperation in organizations. Academy of Management Journal, 38(1), 24-59. http://dx.doi.org/10.2307/256727

Meyerson, G. (2012). Effect of Empowerment on Employees Performance, Advanced Research in Economic and Management Sciences. 2 (July), 40-46.

Murphy, J. T. (2002). Networks, Trust, and Innovation in Tanzania's Manufacturing Sector. World Development, 30(4), 591-619. http://dx.doi.org/10.1016/S0305-750X(01)00131-0

Naderi, N., Jamshidiyan, A. R., \& Salimi, Q. A. (2008). Employees empowerment through in - service training (Isfahan oil refinery company). Journal of the Faculty of Humanities and Social Sciences, 7(27), 121-140.

Nonaka, I., \& Takeuchi, H. (1995). The Knowledge-creating Company. Oxford University Press (Eds.), New York.

Noteboom, B., Van Haverbeke, W. P. M, Duijsters, G. M., Gilsing, V. A., \& Oord, A. V. (2007). Optimal cognitive distance and absorptive capacity. Research Policy, 36(7), 1016-1034. http://dx.doi.org/10.1016/j.respol.2007.04.003

Nunnally, J., \& Bernstein, I. (1994). Psychometric Theory, McGraw Hill, $3^{\text {rd }}$ edition, New York.

Nyhan, R. C. (2000). Changing the paradigm: trust and its role in public sector organizations. American Review of Public Administration, 30(1), 87-109. http://dx.doi.org/10.1177/02750740022064560

Nyhan, R. C., \& Marlowe, H. A. (1997). Development and psychometric properties of the organizational trust inventory. Evaluation Review, 21(5), 614-635. http://dx.doi.org/10.1177/0193841X9702100505

Paliszkiewicz, J. O. (2011). Trust management: literature review. Management, 6(4), 
$315-331$.

Preacher, K. J., \& Hayes, A. F. (2008). Asymptotic and Resampling Strategies for Assessing and Comparing Indirect Effects in Multiple Mediator Models. Behavior Research Methods, 40(3), 879-891. http://dx.doi.org/10.3758/BRM.40.3.879

Randolph, W. A. (1995). Navigating the journey to empowerment. Organizational Dynamics., 23(4), 19-50. http://dx.doi.org/10.1016/0090-2616(95)90014-4

Rousseau, D., Sitkin, S., Burt, R., \& Camerer, C. (1998). Introduction to special topic forum. Not so different after all: A cross-discipline view of trust. Academy of Management Review, 23(4), 393-404. http://dx.doi.org/10.5465/AMR.1998.926617

Sankowska, A. (2013). Relationships Between Organizational Trust, Knowledge Transfer, Knowledge Creation and Firm's Innovativeness. Learning Organization, 20(1), 85-100. http://dx.doi.org/10.1108/09696471311288546

Shockley-Zalabak, P. S., Morreale, S. P., \& Hackman, M. Z. (2010). Building the High-Trust Organization, Jossey-Bass.

Schumpeter, J. A. (1999). Théorie de l'évolution économique, Dalloz, 371P.

Spreitzer, G. M. (1995). Psychological empowerment in the workplace: Dimensions, measurement, and validation. Academy of Management Journal, 38(5), 1442-1465. http://dx.doi.org/10.2307/256865

Thomas, K. B., \& Velthouse, B. A. (1990). Cognition elements of empowerment: an interpretive model of intrinsic task motivation. Academy of Management Review, 15(4), 666-681.

Tremblay, M., Guay, P., \& Simard, G. (2000). L'engagement organisationnel et les comportements discrétionnaires : L'influence des pratiques de gestion des ressources humaines. 11h AFGRH conference proceedings, november 2000, Paris.

Tremblay, M., \& Simard, G. (2005). La mobilisation du personnel : l'art d'établir un climat d'échanges favorables basé sur la réciprocité. Gestion, 30(2), 60-68. http://dx.doi.org/10.3917/riges.302.0060

Vincent, L. H., Bharadwaj, S. G., \& Challagalla, G. N. (2004). Does Innovation Mediate Firm Performance?: A Meta-Analysis of Determinants and Consequences of Organizational Innovation. http://smartech.gatech.edu/handle/1853/10731

Walker, R. M. (2004). Innovation and organizational performance: Evidence and a research agenda. Advanced Institute for Management Research Working Paper. $\mathrm{N}^{\circ} 2$-June. 